\title{
ANALISIS KESULITAN SISWA DALAM MEMECAHKAN SOAL MATEMATIKA BERDASARKAN IDEAL PROBLEM SOLVING PADA MATERI LIMIT FUNGSI
}

\author{
Dhea Andryos Yuntiaji \\ Pendidikan Matemstika, Universitas Muhammadiyah Sukabumi \\ dheashinchan@gmail.com
}

\begin{abstract}
Abstrak
Tujuan dari penelitian ini adalah untuk mengetahui kesulitan dan hambatan siswa dalam memecahkan soal matematika pada materi limit fungsi berdasarkan IDEAL Problem Solving dan juga untuk mengetahui faktor yang mempengaruhi siswa dalam pemecahan masalah soal matematika pada materi limit fungsi. Metode penelitian yang digunakan pada penelitian ini adalah kualitatif deskriptif. Subjek penelitian ini adalah siswa kelas XI IPA MAN 2 Kota Sukabumi dengan menggunakan jenis tes diagnostik dan wawancara. Hasil penelitian menunjukkan berdasarkan model IDEAL Problem solving menunjukkan bahwa siswa masih banyak kesulitan dalam mencari alternatif pemecahan masalah dan pemahaman konsep sehingga dalam penerapan pelaksanaan pemecahan masalah mendapat hasil yang salah atau membuat proses pemecahan masalah tidak efektif. Selain itu siswa masih merasa bingung untuk menemukan metode pemecahan soal matematika khususnya limit fungsi aljabar, di tambah lagi kurang nya pemahaman mengenai konsep dan prinsip limit fungsi aljabar ini membuat siswa mudah lupa sehingga masih belum mampu untuk memecahkan soal limit fungsi.
\end{abstract}

Kata Kunci : Pemecahan Masalah, IDEAL Problem Solving, Kesulitan Siswa.

\begin{abstract}
The purpose of this research was to knowing students difficulties and students obstacle of solving mathematics problem in limit function material based on IDEAL Problem Solving and also to knowing the factor there influence the students to solving the mathematics problems in limit function material. Research method of this research there use is descriptive qualitative. Research subject of thie research was the students in class XI IPA MAN 2 Kota Sukabumi with using diagnostics test and interview. The result of this research was based on IDEAL Problem Solving there showed the students still have a lot difficulties to find the alternative problem solving and understanding the concept so that in application of the alternative problem solving there get a worng answer or make the problem solving process not effective. Be sides that the students still confused to find right the problem solving method specially to limit function of algebra, and then presumably to understanding the concept and principle of this limit function of algebra there make students easy to forget so that make them can't to solving limit function problems.
\end{abstract}

Keywords: Problem Solving, IDEAL Problem Solving, Students difficulties.

\section{Pendahuluan}

Matematika pada hakikatnya merupakan ilmu pengetahuan eksakta yang dipelajari siswa pada setiap jenjang pendidikan dimana menuntut siswanya untuk dapat menghitung, 
memecahkan masalah, berpikir kritis, berpikir logis, sistematis, dan juga siswa harus dapat memahami konsep-konsep matematika yang diberikan sehingga terkadang hal itu membuat siswa merasa kesulitan dalam memecahkan masalah.

Menurut Muhibin Syah (dalam Solekah L. M., Dkk 2017: 151) fenomena kesulitan belajar siswa jelas terlihat pada menurunnya kinerja akademik atau prestasi belajarnya. Karakteristik siswa yang memiliki kesulitan belajar matematika yaitu gangguan hubungan keruangan, abnormalitas Persepsi visual, Asosiasi visual-Motor, Perseverasi, Kesulitan mengenal dan memahami symbol, gangguan penghayatan tubuh, kesulitan dalam bahasa dan membaca, skor performance IQ lebih rendah.

Sebuah penelitian menunjukkan bahwa banyak siswa yang mengalami kesulitan dalam pemecahan soal matematika salah satunya pada materi limit fungsi. Hal ini dibuktikan dengan hasil studi pustaka yang peneliti lakukan dimana seorang peneliti melakukan sebuah penelitian yang dilakukan di SMAN 1 Kasihan yang dilakukan kepada 49 siswa kelas XI IPA 1 dan XI IPA 2 ditemukan bahwa siswa memiliki kesulitan dalam materi limit fungsi. Hal ini dapat dilihat dari sebanyak 25,8\% siswa mengalami kesulitan pada persoalan limit fungsi aljabar di suatu titik. Sebanyak 36,05\% siswa mengalami kesulitan dalam persoalan limit fungsi aljabar tak hingga, 71,4\% siswa mengalami kesulitan dalam limit fungsi trigonometri dan 13 dari 49 siswa melakukan kesalahan pada perhitungan aljabar (Ardiyanti Rosa, $2016: 1$ ).

Permasalahan pemecahan masalah dalam matematika ini salah satunya pada materi limit fungsi. Limit fungsi ini merupakan materi yang terdapat pada jenjang SMA/MA sederajat. Limit matematika merupakan konsep dasar untuk materi didalam kalkulus differensial maupun integral.

Pemecahan masalah pada matematika merupakan salah satu indikator yang penting untuk dikuasai oleh siswa. Pemecahan masalah merupakan komponen penting dari kurikulum matematika dan di dalamnya terdapat inti dari aktivitas matematika, sehingga kemampuan pemecahan masalah di kalangan siswa perlu mendapat perhatian dalam pembelajaran (dalam Nayazik, A. Sukestiarno. 2012:2). Menurut Indriyani dan Masriayah (2016:101) pemecahan masalah, juga sangat diperlukan untuk mengetahui tingkat penguasaan siswa terhadap materi pelajaran dan untuk melatih siswa agar mampu menerapkan pengetahuan yang dimilikinya ke dalam berbagai situasi dan masalah yang berbeda.

Model pembelajaran yang dapat dikembangkan untuk meningkatkan kemampuan pemecahan masalah pada siswa yaitu model pembelajaran IDEAL Problem Solving. Model pembelajaran ini diperkenalkan oleh Bransford dan Stein (dalam Nayazik, A. Sukestiarno. 
2012:2) sebagai penedekan yang dapat membantu untuk menyelesaian masalah. IDEAL merupakan singkatan dari I (Indentify problem), D (Define goals), E (Explore possible strategies), A (Anticipate outcomes and act) dan L (Look back and learn). Dan model pembelajaran ini dapat digunakan untuk menyelesaiakn masalah dengan masalah atau soal yang terdefinisi dengan baik (well-structured problem).

Adapun langkah-langkah IDEAL problem solving sesuai dengan singkatan IDEAL adalah (1) mengidentifikasi masalah, (2) mendefinisikan tujuan, (3) menggali solusi, (4) melaksanakan strategi, (5) mengkaji kembali dan mengevaluasi dampak dari pengaruh (dalam Nayazik, A. Sukestiarno. 2012:2). Dari langkah-langkah diatas dapat kita ketahui bahwa model pembelajaran tersebut dapat meningkatkan kemampuan siswa didalam pemecahan masalah.

Masalah yang dihadapi siswa khususnya masalah pada pembelajaran matematika haruslah diselesaikan sesuai dengan prosedur yang sistematis. Diana (Indriyani dan Masriayah. 2016:102) menyatakan bahwa masalah matematika adalah soal matematika yang tidak mampun diselesaikan dengan prosedur rutin melainkan menggunakan berbagai keterampilan dan pengetahuan yang dimiliki untuk memecahkan masalahnya.

Berdasarkan latar belakang diatas, penulis tertarik melakukan penelitian mengenai “Analisis Kesulitan Siswa Dalam Memecahkan Soal Matematika Berdasarkan IDEAL Problem Solving Pada Materi Limit Fungsi”. Adapaun tujuan dari penelitian ini adalah untuk (1) Mengetahui kesulitan-kesulitan atau hambatan siswa dalam memecahkan Soal matematika pada materi limit fungsi berdasarkan IDEAL problem solving dan (2) mengetahui faktor yang mempengaruhi siswa dalam pemecahan soal matematika pada materi limit fungsi.

\section{Metode Penelitian}

Dalam penelitian ini, jenis penelitian yang digunakan adalah metode penelitian kualitatif deskriptif. Penelitian ini dilakukan untuk memperoleh pengertian mendalam mengenai situasi dan makna sesuatu/subjek yang diteliti Masrukhin 2009 (dalam Ulya Himmatul 2016 : 92). Pada penelitian kualitatif ini merupakan penelitian yang purposive atau memiliki tujuan yang menjadikan peneliti sebagai instrument utama dalam penelitian.

Penelitian ini akan dilaksanakan pada bulan April - Mei 2019. Tempat penelitian akan dilaksanakan di MAN 2 Kota Sukabumi di kelas XI IPA tahun ajaran 2018/2019. Subjek penelitian dalam penelitian ini adalah siswa kelas XI MIPA di MAN 2 Kota Sukabumi tahun ajaran 2018/2019 yang merupakan salah satu Madrasah Aliyah Negeri di Kota Sukabumi. Pada penelitian ini peneliti mengambil secara random subjek sebanyak 6 orang dari kelas XI MIPA. 
Metode pengumpulan data yang digunakan dalam penelitian ini adalah teknik tes diagnostic yaitu tes yang dapat mengukur kemampuan pemecahan masalah siswa pada soal limit fungsi dan non tes yang berupa wawancara untuk mendapatkan data mengenai factor yang membuat siswa sulit untuk mendapatkan pemecahan masalah soal limit fungsi .

Analasis data yang digunakan dalam penelitian ini terdiri dari dua tahapan yaitu analisis sebelum di lapangan dan analisis setelah selama dilapangan. Analisis data sebelum dilapangan peneliti melakukan validasi instrument yang berupa tes pemecahan masalah dan juga pedoman wawancara. Pada analisis data selama dilapangan peneliti mencari dan mengumpulkan data dengan sistematis pada hasil yang diperoleh dari tes pemecahan maslah dan wawancara. Kemudian dilanjutkan dengan teknik analisis data dengan metode perbandingan tetap. Menurut Lexy J. Moleong (dalam Apriyanti Rosa 2016 : 5) yaitu membandingkan datu datum dengan datum yang lain serta kategori satu dengan yang lainnya.

\section{Hasil Dan Pembahasan}

Penelitian yang dilaksanakan pada bulan April - Mei 2019 bertempat di MAN 2 Kota Sukabumi dengan subjek penelitian adalah siswa kelas XI IPA. Penelitian ini menggunakan instrumen tes dan wawancara.

Pada tanggal 05 Mei 2019 peneliti melakukan tes diagnostik kepada siswa kelas XI IPA berupa 8 butir soal berbentuk essay. Peserta yang melaksanakan tes diagnostik ini adalah 6 siswa yang terdiri dari siswa kelas 1 orang siswa kelas XI IPA A, 2 orang siswa kelas XI IPA B, 1 orang siswa kelas XI IPA C, 1orang siswa kelas XI IPA D, dan 1 orang siswa kelas XI IPA E.

Hasil dari tes diagnostik tersebut di koreksi dan di analisis oleh peneliti. Dengan skor maksimum 100, ditemukan fakta bahwa :

1. Sebanyak 1 orang siswa dapat mengerjakan 8 soal dengan benar

2. Sebanyak 1 orang siswa dapat mengerjakan 6 soal dengan benar

3. Sebanyak 1 orang siswa dapat mengerjakan 4 soal dengan benar

4. Sebanyak 3 orang siswa dapat mengerjakan 1 soal dengan benar

\section{A. Kajian Tes Diagnostik Limit Fungsi (Limit Fungsi Aljabar)}

\section{Kajian Soal Nomor 1 ( soal limit fungsi aljabar terhadap suatu titik)}

$$
\text { Nilai } \lim _{x \rightarrow 4} \frac{x+\sqrt{1+x^{2}}}{4}=\ldots
$$


Pada proses penyelesaian soal ini siswa dapat memahami konsep yaitu dengan mensubstitusikan nilai $x$ menjadi bilangan 4 ke dalam fungsi. Bukti penyelesaian soal nomor 1 adalah sebagai berikut:

$$
\lim _{x \rightarrow 4} \frac{x+\sqrt{1+x^{2}}}{4}=\frac{4+\sqrt{1+4^{2}}}{4}=\frac{4+\sqrt{17}}{4}
$$

Konsep yang digunakan pada soal ini adalah $\lim _{x \rightarrow c} f(x)=P$ dengan prinsip pada soal ini adalah Untuk menghitung nilai dari limit diatas siswa hanya perlu untuk menghitung nilai limit tersebut di $x=4$.

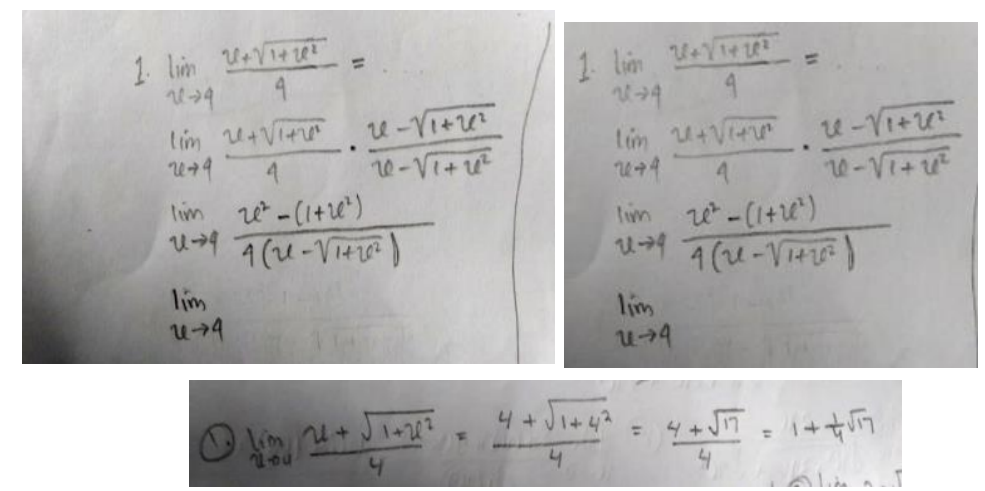

Gambar 1. Hasil pengerjaan siswa pada soal nomor 1.

Dari hasil analisis menunjukkan masih ada siswa yang memiliki kesalahan dalam mengerjakan soal nomor 1 ini. Kesalahan yang dilakukan siswa adalah mencari alternatif pemecahan masalah yang sesuai. Kesalahan yang dilakukan adalah siswa tidak mensubtitusikan nilai x menjadi bilangan 4 ke dalam fungsi, tetapi siswa mengalikan fungsi tersebut dengan fungsi sekawan dari pembilangnya sehingga menghasilkan pemecahan masalah yang kurang efektif. Dalam soal ini ada beberapa siswa yang menjawab benar, tetapi ada 1 orang siswa yang masih melakukan kesalahan dalam mencari alternatif pemecahan masalah ini sehingga menghasilkan jawaban yang salah.

\section{Kajian Soal Nomor 2 (soal limit fungsi aljabar tehadap suatu titik)}

$$
\text { Jika } \mathrm{f}(\mathrm{x})=\frac{\sqrt{x}-\sqrt{2 x-1}}{x-1}, \text { maka } \lim _{x \rightarrow 1} f(x)=\ldots
$$

Soal ini memiliki tujuan untuk mengetahui kemampuan dari siswa mengenai pemahaman konsep dan analisis siswa terhadap tipe soal yang tidak umum atau memiliki analasis untuk menyelesaikannya. Siswa diminta untuk dapat menuliskan kembali apa yang di tanyakan di dalam soal dan nilai dari limit terhadap suatu titik berdasarkan dari informasi yang terdapat di dalam soal. Bukti penyelesaian soal tersebut adalah :

Jika $f(x)=\frac{\sqrt{x}-\sqrt{2 x-1}}{x-1}$, 


$$
\begin{aligned}
& \text { maka } \lim _{x \rightarrow 1} f(x)=\lim _{x \rightarrow 1} \frac{\sqrt{x}-\sqrt{2 x-1}}{x-1} \\
& \begin{aligned}
\lim _{x \rightarrow 1} \frac{\sqrt{x}-\sqrt{2 x-1}}{x-1}=\lim _{x \rightarrow 1} \frac{\sqrt{x}-\sqrt{2 x-1}}{x-1} \cdot \frac{\sqrt{x}+\sqrt{2 x-1}}{\sqrt{x}+\sqrt{2 x-1}} \\
=\lim _{x \rightarrow 1} \frac{1-x}{(x-1)(\sqrt{x}+\sqrt{2 x-1})} \\
=\lim _{x \rightarrow 1}-\frac{1}{(\sqrt{x}+\sqrt{2 x-1})} \\
=-\frac{1}{2}
\end{aligned}
\end{aligned}
$$

Konsep yang digunakan pada soal ini adalah $\lim _{x \rightarrow c} f(x)=P$ maknanya, jika $x$ dekat tetapi berlainan dengan $c$, maka $f(x)$ dekat dengan P. Prinsip pada soal ini adalah Untuk mengetahui nilai dari limit pada soal nomor 2 yang harus di lakukan adalah dengan menuliskan kembali apa yang ditanyakan di dalam soal, dengan menggunakan informasi di dalam soal yaitu dengan memasukkan $\mathrm{F}(\mathrm{x})$ sebagai $\mathrm{f}(\mathrm{x})$ dalam $\lim _{x \rightarrow 1} f(x)=$ $\lim _{x \rightarrow 1} \frac{\sqrt{x}-\sqrt{2 x-1}}{x-1}$, kemudian dikalikan dengan sekawan fungsi pembilangnya.
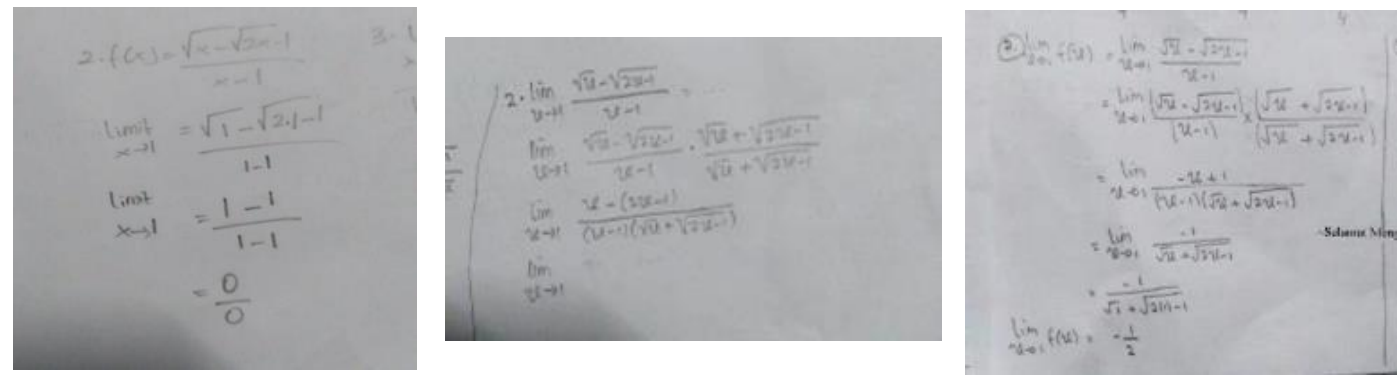

Gambar 2. Hasil pengerjaan siswa pada soal nomor 2.

Dari hasil analisis terdapat siswa yang sudah mampu memecahkan soal tanpa kesalahan. Namun masih ada siswa yang melakukan kesalahan pada proses pencarian alternative pemecahan masalah. Dimana siswa masih melakukan kesalahan dengan tidak mengalikan fungsi dengan sekawan fungsinya. Hanya mensubtitusikan $x$ menjadi bilangan 1. Sehingga menghasilkan hasil yang tidak tepat. Kemudian masih ada siswa yang masih melakukan kesalahan dalam menerapkan pelaksanaan perencanaan pemecahan masalah untuk memperoleh penyelesaian dari soal yang di berikan. Siswa masih bingung untuk menentukan langkah selanjutnya dalam penerapan pelaksanaan pemecahan masalah. Dalam soal nomor 2 juga ada siswa yang sudah dapat mengerjakan soal dengan benar.

\section{Kajian Soal Nomor 3 (soal limit fungsi aljabar terhadap titik nol)}

$$
\text { Nilai } \lim _{x \rightarrow 0} \frac{2-\sqrt{x+4}}{x^{2}-x}=\ldots
$$


Pada soal ini siswa di minta untuk dapat menemukan nilai dari limit sebuah fungsi, dimana pada pengerjaannya siswa harus mengalikan fungsi tersebut dengan sekawan fungsi pembilangnya. Bukti penyelesaian soal sebagai berikut :

$$
\begin{aligned}
\lim _{x \rightarrow 0} \frac{2-\sqrt{x+4}}{x^{2}-x} & =\lim _{x \rightarrow 0} \frac{2-\sqrt{x+4}}{x^{2}-x} \cdot \frac{2+\sqrt{x+4}}{2+\sqrt{x+4}} \\
& =\lim _{x \rightarrow 0} \frac{4-(x+4)}{\left(x^{2}-x\right)(2+\sqrt{x+4})} \\
& =\lim _{x \rightarrow 0} \frac{4-x-4}{\left(x^{2}-x\right)(2+\sqrt{x+4})} \\
& =\lim _{x \rightarrow 0} \frac{-x}{\left(x^{2}-x\right)(2+\sqrt{x+4})} \\
& =\lim _{x \rightarrow 0} \frac{-x}{x(x-1)(2+\sqrt{x+4})} \\
& =\lim _{x \rightarrow 0} \frac{-1}{(x-1)(2+\sqrt{x+4})} \\
& =\frac{-1}{(-1)(2+\sqrt{4)}}=\frac{-1}{(-1)(4)}=\frac{1}{4}
\end{aligned}
$$

Konsep yang digunakan adalah $\lim _{x \rightarrow c} f(x)=P$ maknanya bahwa jika $x$ dekat tetapi berlainan dengan $c$, maka $f(x)$ dekat dengan P. Prinsipnya adalah Mengalikan fungsi tersebut dengan sekawan fungsi pembilang dari fungsi yang ada.
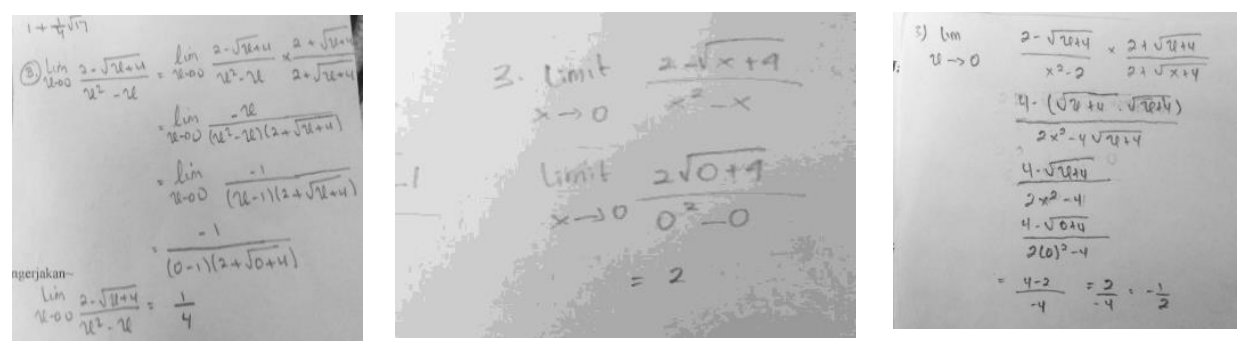

Gambar 3. Hasil pengerjaan siswa pada soal nomor 3.

Dari hasil analisis dapat dilihat terdapat siswa yang masih kurang tepat dalam menemukan alternative pemecahan masalah. Terlihat ada siswa yang menggunakan pengerjaan dengan mensubtitusi $x$ menjadi bilangan 0 sehingga menghasilkan jawaban yang salah. Ditemukan juga kesalahan dalam penerapan pelaksanaan pemecahan masalah dimana ditemukan kesalahan dalam penghitungan aljabar meskipun menggunakan cara yang sama tetapi menghasilkan jawaban yang salah. Beberapa siswa sudah ada yang mampu menjawab dengan benar. Dan 1 orang siswa tidak dapat menjawab soal.

\section{Kajian Soal Nomor 4 (soal limit fungsi aljabar terhadap suatu titik)}

$$
\text { Nilai dari } \lim _{x \rightarrow 2}\left(\frac{x^{2}-8}{x-2}+\frac{x^{2}-2 x}{2 x-4}\right) \text { adalah... }
$$

Pada soal ini siswa di minta untuk dapat menemukan nilai dari sebuah limit. Dengan cara memfaktorkan salah satu fungsi agar dapat menjadi fungsi yang lebih sederhana, 
kemudian mencari nilai limit fungsi dengan mensubtitusikan $x$ menjadi bilangan 2. Berikut bukti penyelesaian soal, sebagai berikut :

$$
\begin{aligned}
\lim _{x \rightarrow 2}\left(\frac{x^{2}-8}{x-2}+\frac{x^{2}-2 x}{2 x-4}\right)= & \lim _{x \rightarrow 2}\left(\frac{x^{2}-8(2 x-4)+(x-2)\left(x^{2}-2 x\right)}{(x-2)(2 x-4)}\right)=\lim _{x \rightarrow 2}\left(\frac{2 x^{3}+x^{3}-4 x^{2}-4 x^{2}-16 x+4 x+32}{2 x^{2}-8 x+8}\right)= \\
& \lim _{x \rightarrow 2}\left(\frac{4 x^{3}-8 x^{2}-12 x+32}{2 x^{2}-8 x+8}\right)=\lim _{x \rightarrow 2}\left(\frac{4\left(x^{3}-2 x^{2}-3 x+8\right)}{2\left(x^{2}-4 x+4\right)}\right)=\lim _{x \rightarrow 2}\left(\frac{2\left(x^{3}-2 x^{2}-3 x+8\right)}{\left(x^{2}-4 x+4\right)}\right)= \\
& \frac{2\left(2^{3}-2\left(2^{2}\right)-3(2)+8\right)}{2^{2}-4(2)+4}=\frac{4}{0}=\infty
\end{aligned}
$$
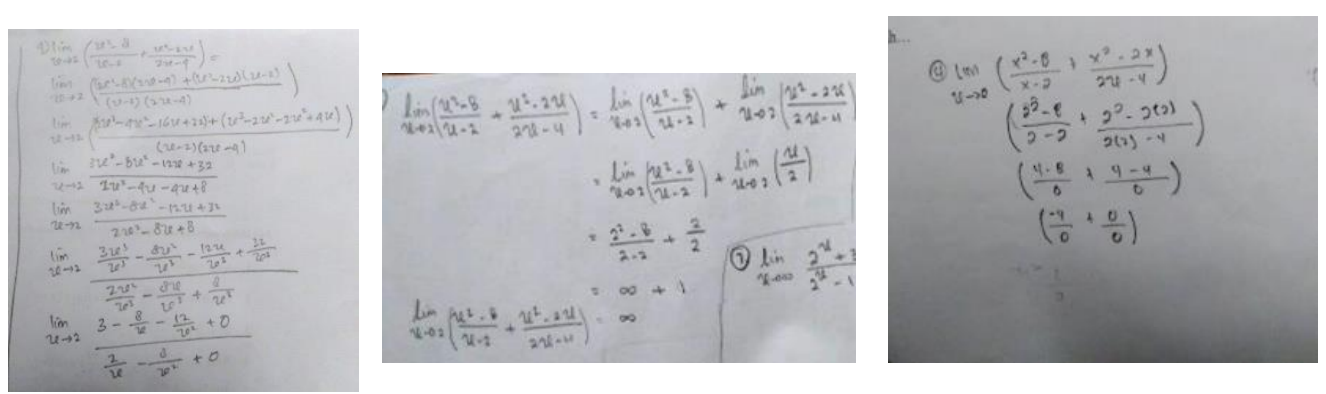

Gambar 4. Hasil pengerjaan siswa pada soal nomor 4.

Dari hasil analisis terdapat siswa yang melakukan kesalahan dalam mencari alternative pemecahan masalah. Pada soal ini siswa seharusnya menggunakan pemfaktoran dalam penyelesaian soal kemudian mensubtitusi $x$ menjadi bilangan 2. Namun ada siswa yang masih belum faham mengenai konsep tersebut, seperti menggunakan perkalian sekawan fungsi dan mensubtitusikan $x$ menjadi bilangan tanpa menyederhanakan fungsi sehingga pengerjaan tidak efektif yang menyebabkan hasil yang di dapat salah. Namun ada siswa yang sudah dapat mengerjakan dengan cara yang sama dan dengan hasil yang benar.

\section{Kajian Soal Nomor 5 (soal limit fungsi aljabar terhadap suatu titik)}

$$
\text { Jika } \lim _{x \rightarrow 0} \frac{p(x-3)}{2 x^{2}-5 x-3}=2 \text {, maka nilai } p \text { yang memenuhi adalah... }
$$

Untuk memecahkan soal ini siswa hanya perlu memahami konsep limit fungsi dimana hanya perlu untuk mensubtitusikan $x$ menjadi bilangan 2 kepada fungsi yang sudah ada. Bukti penyelesaian dari soal diatas adalah :

$$
\begin{aligned}
& \lim _{x \rightarrow 0} \frac{p(x-3)}{2 x^{2}-5 x-3}=2, \text { maka nilai } \mathrm{p}=? \\
& \lim _{x \rightarrow 0} \frac{p(x-3)}{2 x^{2}-5 x-3}=2 \\
& \frac{p((0)-3)}{2(0)^{2}-5(0)-3}=2 \\
& \frac{p(-3)}{-3}=2
\end{aligned}
$$


$p=2$
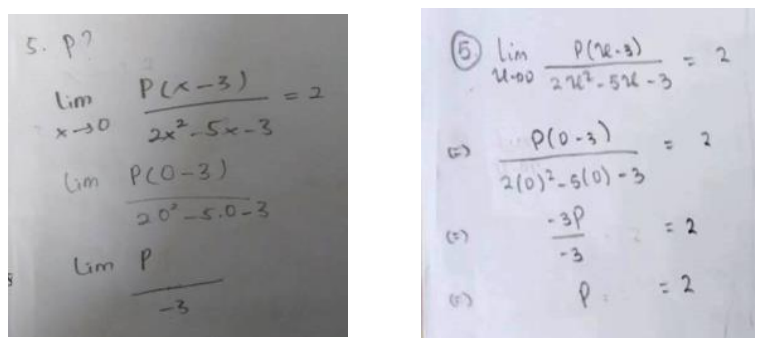

Gambar 5. Hasil pengerjaan siswa pada soal nomor 5.

Dari hasil analisis, 4 siswa sudah dapat menyelesaikan soal dengan benar menggunakan cara mensubtitusikan $x$ menjadi bilangan 0 kedalam fungsi. Namun ada siswa yang melakukan kesalahan pada penerapan pelaksanaan pemecahan masalah yaitu kesalahan dalam penghitungan aljabar sehingga jawaban tidak ditemukan. Dan 1 dari 6 siswa tidak menjawab soal.

\section{Kajian Soal Nomor 6 (soal limit fungsi aljabar terhadap suatu titik)}

$$
\text { Nilai } \lim _{x \rightarrow \infty} \sqrt{x^{2}+2 x}-\sqrt{x^{2}}=\ldots
$$

Pada soal ini siswa diminta untuk dapat menemukan nilai dengan cara mengalikan fungsi tersebut dengan sekawan fungsi nya. Berikut bukti penyelesaian soal:

$$
\begin{aligned}
& \lim _{x \rightarrow \infty} \sqrt{x^{2}+2 x}-\sqrt{x^{2}}=\lim _{x \rightarrow \infty} \sqrt{x^{2}+2 x}-\sqrt{x^{2}} \cdot \frac{\sqrt{x^{2}+2 x}+\sqrt{x^{2}}}{\sqrt{x^{2}+2 x}+\sqrt{x^{2}}} \\
& =\lim _{x \rightarrow \infty} \frac{\left(\sqrt{x^{2}+2 x}-\sqrt{x^{2}}\right)\left(\sqrt{x^{2}+2 x}+\sqrt{x^{2}}\right)}{\sqrt{x^{2}+2 x}+\sqrt{x^{2}}} \\
& =\lim _{x \rightarrow \infty} \frac{\left(x^{2}+2 x\right)-x^{2}}{\sqrt{x^{2}+2 x}+\sqrt{x^{2}}} \\
& =\lim _{x \rightarrow \infty} \frac{2 x}{\sqrt{x^{2}+2 x}+\sqrt{x^{2}}} \\
& =\lim _{x \rightarrow \infty} \frac{2 x}{x\left(\sqrt{1+\frac{2}{x}}+1\right)} \\
& =\lim _{x \rightarrow \infty} \frac{2}{\left(\sqrt{1+\frac{2}{x}}+1\right)} \\
& =\frac{2}{\sqrt{1}+1}=\frac{2}{1+1}=\frac{2}{2}=1
\end{aligned}
$$
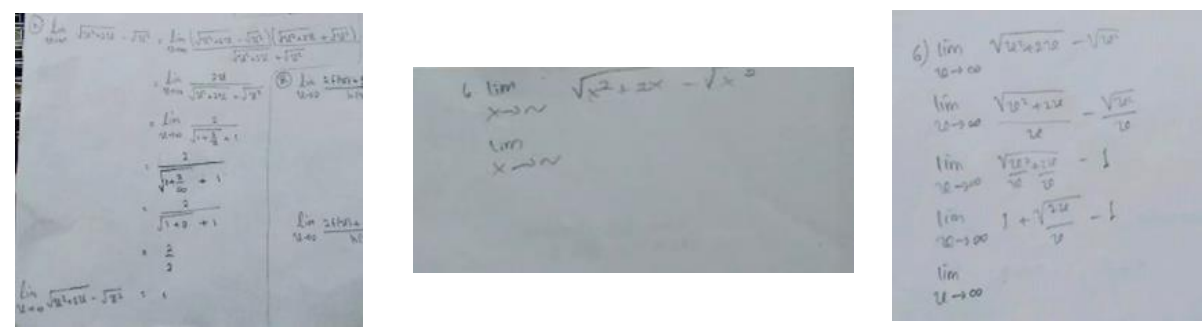

Gambar 6. Hasil pengerjaan siswa pada soal nomor 6. 
Dari hasil analisis, 2 siswa sudah dapat menyelesaikan soal dengan benar. Dengan menggunakan cara mengalikan fungsi dengan sekawan fungsi nya. Namun masih ada siswa yang melakukan kesalahan pada proses pencarian pemecahan masalah, terlihat siswa masih kurang memahami konsep perkalian sekawan sehingga mendapat pengerjaan yang kurang efektif hal ini menyebabkan hasil yang di dapat salah. 2 dari 6 siswa tidak menjawab soal.

\section{Kajian Soal Nomor 7 (soal limit fungsi aljabar terhadap suatu titik)}

$$
\text { Nilai dari } \lim _{x \rightarrow \infty} \frac{2^{x}+3}{2^{x}-1} \text { adalah... }
$$

Pada soal ini bertujuan untuk mengetahui pemahaman siswa pada konsep limit sekaligus untuk mengetahui bagaimana cara siswa untuk memecahkan soal yang memerlukan kreativitas dalam mengkombinasikan konsep. Pada soal ini terdapat konsep dimana nilai limit di tak hingga jika berbentuk $\frac{p}{x^{n}}$ maka bernilai nol. Bukti penyelesaian sebagai berikut:

$$
\begin{aligned}
\lim _{x \rightarrow \infty} \frac{2^{x}+3}{2^{x}-1} & =\lim _{x \rightarrow \infty} \frac{\frac{2^{x}+3}{2^{x}}}{\frac{2^{x}-1}{2^{x}}} \\
& =\frac{1+\frac{3}{2^{x}}}{1-\frac{1}{2^{x}}} \\
& =\frac{1+\frac{3}{2^{\infty}}}{1-\frac{1}{2^{\infty}}} \\
& =\frac{1+0}{1-0}=\frac{1}{1}=1
\end{aligned}
$$
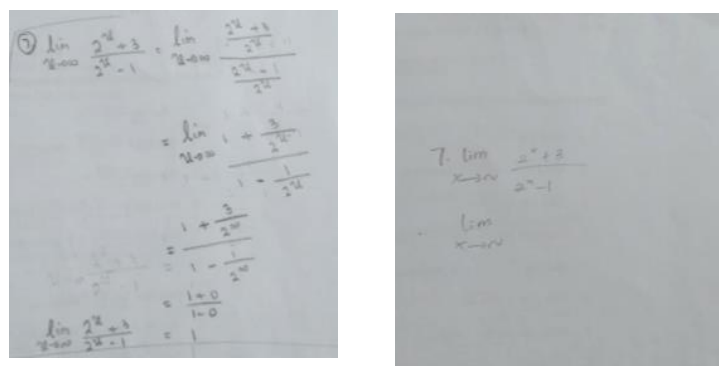

Gambar 7. Hasil pengerjaan siswa pada soal nomor 7.

Dari hasil analisis, hanya 1dari 6 siswa yang dapat mengerjakan soal dengan benar dan Sisanya tidak mengerjakan soal.

\section{Kajian Soal Nomor 8 (soal limit fungsi aljabar terhadap suatu titik)}

Jika $\lim _{x \rightarrow 0} f(x)=3, \lim _{x \rightarrow 0} g(x)=-5, \lim _{x \rightarrow 0} h(x)=\frac{1}{2}$, maka nilai dari $\lim _{x \rightarrow 0} \frac{(2 f(x)+g(x))}{h(x)}$ adalah...

Pada soal ini siswa diharapkan dapat memahami konsep dan dapat mengaplikasikannya. Siswa diminta untuk menemukan nilai dari sebuah limit dengan hanya mensubtitusikan nilai dari beberapa fungsi. 


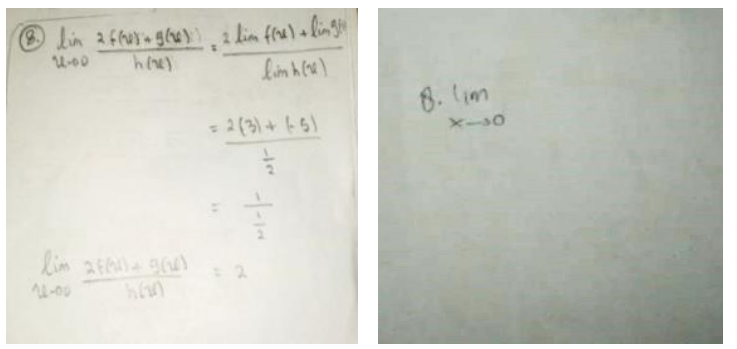

Gambar 8. Hasil pengerjaan siswa pada soal nomor 8.

Dari hasil analisis 3 dari 6 siswa sudah dapat mengerjakan soal dengan menggunakan alternative pemencahan yang benar. Namun 3 siswa lainnya tidak dapat mengisi soal nomor 8 karena belum menemukan alternative pemecahan masalah yang benar.

Kesulitan siswa dalam memecahkan masalah pada soal limit fungsi dapat kita lihat pada hasil analisis kajian soal limit fungsi aljabar. Hasil analisis menunjukkan bahwa siswa masih banyak melakukan kesalahan dalam mencari alternatif pemecahan masalah dan pemahaman konsep sehingga dalam penerapan pelaksanaan pemecahan masalah mendapat hasil yang salah atau membuat proses pemecahan masalah tidak efektif, terlihat pada hasil kajian soal nomor 2, $3,4,6,7,8$.

Beberapa konsep mengenai limit baik limit di suatu titik, di nol, dan di tak hingga masih belum di pahami siswa, misalnya konsep nilai limit di tak hingga berbentuk $\frac{p}{x^{n}}$ adalah nol hal ini dapat dilihat pada kajian soal nomor 7 hanya satu siswa yang sudah memahami konsep limit ini.

Terdapat siswa yang masih salah dalam menggunakan alternative pemecahan masalah. Metode untuk memecahkan soal limit. Jika seharusnya menggunakan metode perkalian sekawan tetapi menggunkan metode subtitusi $\mathrm{x}$ menjadi bilangan, jika seharusnya menggunakan metode faktorisasi fungsi tetapi menggunakan metode subtitusi $\mathrm{x}$ menjadi bilangan.

Pada hasil wawancara yang telah dilakukan untuk mengetahui alasan mengapa siswa masih mengalami kesulitan dalam memecahkan soal limit tersebut, siswa masih merasa bingung untuk menemukan metode pemecahan soal matematika khususnya limit fungsi aljabar, di tambah lagi kurang nya pemahaman mengenai konsep dan prinsip limit fungsi aljabar ini membuat siswa mudah lupa sehingga masih belum mampu untuk memecahkan soal limit fungsi dan juga siswa merasa pada saat pemaparan materi yang terlalu cepat dan kurangnya inovasi untuk mempermudah siswa memahami materi limit fungsi. 


\section{Simpulan dan Saran}

Dari hasil penelitian yang sudah dilakukan, maka ditemukan bahwa kesulitan siswa dalam memecahkan masalah soal matematika pada soal limit fungsi adalah terdapat 1 siswa yang sudah mampu menemukan alternative pemecahan masalah, dan dan penerapan pemecaan masalah berdasarkan IDEAL Problem Solving . factor yang mendorong siswa tersebut adalah factor internal dengan penguatan pemahaman konsep dan materi limit. Namun dari 5 siswa lainnya masih mengalami kesulitan dalam pemecahan masalah soal matematika pada soal limit fungsi. Berdasarkan model IDEAL Problem Solving siswa masih merasa kesulitan pada tahap menentukan alternative pemecahan masalah, dan juga penerapan dari pemecahan masalah yang di sudah dipilih. Hal ini di dorong dengan kurang nya pemahaman konsep dan juga prinsip dari materi limit fungsi.

Berdasarkan dari simpulan diatas, maka dibutuhkan adanya beberapa inovasi dalam pemaparan materi limit fungsi dengan menggunakan model pemecahan masalah yang sesuai dengan karakteristik siswa sehingga siswa mampu untuk memecahkan soal matematika khususnya pada limit fungsi.

\section{Referensi}

Ardiyanti Rosa, Murdanu. 2016. Analisis Kesulitan Mempelajari Materi Limit Fungsi Siswa Kelas XI IPA SMAN 1 Kasihan 2013/2014. UNY Jurnal Pendidikan Matematika. 1-11.

Indriyani.R.W, Masriyah. 2016. Penerapan Model Pembelajaran IDEAL Probelem solving dalam Menyelesaikan Masalah Matematika pada Materi Keliling dan Luas Persegi Panjang dan Persegi Bagi Siswa Kelas VII SMP. Mathedunesa:Jurnal Ilmiah Pendidikan Matematika. (2).(5). 100-108.

Nayazik.A, Sukestiyono. 2012. Pembelajaran Matematika Model IDEAL Problem Solving dengan Teori Pemrosesan Informasi untuk Pembentukan Pendidikan Karakter dan Pemecahan Masalah Materi Dimesi Tiga Kelas X SMA. Pyhtagoras. (7).(2). 1-8.

Solekah Laili Ma'atus, Dewi Anggraeni, Adi Waluyo. 2017. Analisis Kesulitan Siswa Dalam Menyelesaikan Soal Matematika Ditinjau Dari Koneksi Matematis Materi Limit Fungsi. STKIP PGRI Tulungagung Wacana Akademika. (1).(2). 151-164.

Ulya. Himmatul. 2016. Profil kemampuan Pemecahan Masalah Siswa Bermotivasi Belajar Tinggi Berdasarkan Ideal Problem Solving.Universitas Muria Kudus Jurnal Konseling. (2).(1). 90-96. 